Portland State University

PDXScholar

2-27-2019

\title{
Identifying Models of Obsidian Distribution in Preclassic Maya Lowlands Contexts
}

Sabine Tischler

Portland State University

Follow this and additional works at: https://pdxscholar.library.pdx.edu/honorstheses

Let us know how access to this document benefits you.

\section{Recommended Citation}

Tischler, Sabine, "Identifying Models of Obsidian Distribution in Preclassic Maya Lowlands Contexts" (2019). University Honors Theses. Paper 658.

https://doi.org/10.15760/honors.672

This Thesis is brought to you for free and open access. It has been accepted for inclusion in University Honors Theses by an authorized administrator of PDXScholar. Please contact us if we can make this document more accessible: pdxscholar@pdx.edu. 
Identifying models of obsidian distribution in Preclassic Maya Lowlands contexts

by

\begin{abstract}
Alex Tischler
An undergraduate honor thesis submitted in partial fulfillment of the requirements for the degree of

Bachelor of Arts

in

University Honors

and

Anthropology
\end{abstract}

Thesis Advisor

Professor Sarah Sterling

Portland State University

2019 


\title{
Identifying models of obsidian distribution in Preclassic Maya Lowlands contexts
}

\author{
Alex Tischler
}

\begin{abstract}
Obsidian was an important resource throughout Mesoamerica, and found at nearly all sites. Sources of obsidian were located in the Mexican Highlands and Guatemalan Highlands, often being transported over hundreds of kilometers for distribution. In this paper I chose four Maya sites-EI Ceibal, Tikal, Xtobo, and Actun Uayazba Kab-and used three obsidian distribution models previously published by De León et al. in 2009, to infer possible distribution methods used in the Maya Lowlands. Though limitations existed the results from this proof-of-concept analysis indicate that distribution models derived for central Mexican contexts are suitable for Maya regions, and that the Maya were engaged in multiple forms of blade trade.
\end{abstract}

\section{Introduction}

Obsidian has long been an important material for lithic using populations where available. The dark volcanic glass is naturally sharp when fractured, and its predictable flaking patterns made it a highly prioritized material for flintknapping efficient lithic blades. Situated within the tectonic active Pacific Rim of Fire, Mesoamerica had over a dozen obsidian quarries frequented for centuries by the numerous Mesoamerican populations. The majority of these quarries were in the Mexican Highlands—Zaragoza, Orizaba, Paredon, Otumba, Tulancingo, Pachuca, Zacualtipan, and Ucareo quarries - west of the Isthmus of Tehuantepec, while to the east, those in the Mexican lowlands, Guatemala, Belize, El Salvador, and Honduras predominately exploited obsidian from the Guatemalan Highlands-El Chayal, Ixtepeque, San Martín Jilotepeque, and Tajumulco.

Mesoamerican obsidian sources were exploited by preceramic Paleo-Indigenous peoples before the beginning of the Archaic era around 7,000 B.C.E. (Coe and Flannery 1964:46,48; Brown 1980: 314-316,322). The Archaic Era ( 7,000 B.C.E. - 1,500 B.C.E.) is most pronounced 
by the adoption of sedentary settlements and swidden agricultural methods including domestication of staple crops (maize and squash) by 3,400 B.C.E and extending even into the Preclassic (Lohse 2010:320; Adams 2005:33). Additionally, pottery begins appearing near the end of the Archaic, such as the early Tehuacan sequence from Puerto Márquez (Adams 2005:45). Sedentary settlements of the Archaic gave way to growing social complexity and the first Mesoamerican states during the Preclassic Era (1,500 B.C.E. -250 C.E.). Urban civil centers started becoming cores of Mesoamerican villages, and were marked by the construction of stone monuments and ballcourts (Adams 2005:59-60). Pan-Mesoamerican iconography began spreading along a growing number of long-distance interregional trade networks. The longdistance trade of obsidian prismatic blades too became more sophisticated. Obsidian prismatic flake blades were commonly traded during the Early and Middle Preclassic, giving way to the trade of obsidian prismatic cores by the Late Preclassic (De León et al. 2009).

For archaeologists, obsidian artifacts provide valuable resources in the reconstruction of the ancient trade networks. All obsidian sources, have unique chemical composition which makes possible the accurate sourcing of obsidian artifacts. Connecting samples recovered at sites to the original quarry has allowed for intricate analyses of obsidian trade routes, distribution methods, and trade partners. Additionally, the evolution of sophisticated obsidian flintknapping technology cultures has been used to infer spread of technologies and ideas, or changes in trade partners. While obsidian artifacts can reveal much, "most research still emphasizes the gathering of source-attribution data rather than the analysis of exchange mechanisms" (Braswell et al. 2000). And of these Preclassic trade network models, the majority are largely reconstructed from sites in the Mexican Highlands (De León et al. 2009). 
Three of the experienced researchers of Preclassic Mesoamerican obsidian assemblages and sourcing, Jason De León, Kenneth Hirth, and David Carballo, proposed a series of obsidian prismatic blade distribution models: whole-blade trade, processed-blade trade, and local-blade production. In supporting their models De León et al. only used sites from Highland Mexico. In this paper I will be using De León et al.'s proposed models for obsidian distributions and apply them to obsidian assemblages recovered from Preclassic Maya contexts. The goal is to determine if Preclassic Maya obsidian usage is preserved in the archaeological record in a manner comparable to Highland Mexican contexts, such that models of obsidian distribution conceptualized for Highland Mexican obsidian sources are applicable to Maya sites.

\section{Methodology}

\section{Obsidian}

Obsidian is a glassy rhyolitic igneous rock, a product of volcanic processes. Formed from rapidly cooling felsic magma, obsidian flows are chemically homogenous and have a disorderly atomic structure, resulting in the lack of a mineral crystalline structure in its matrix customary of felsic rocks such granite (Andrefsky 2005; Ferguson 2012). The lacking crystalline matrix allows for predictable fracturing and worked edges to be sharper than steel due to a thinner atomic structure.

Pure obsidians are naturally dark in color, purples and blacks, but can range in a variety of colors due to impurities: brown, grey, blue, green, white, and red. Samples may be monochromatic, or be imbued with white bursts ("snowflake" obsidian), stripes of one or more color, or even a multitude of colors ("rainbow" obsidian) (Nadin 2007). These impurities are caused by presence of trace elements of zinc $(\mathrm{Zn})$, iron $(\mathrm{Fe})$ and iron oxide $\left(\mathrm{Fe}_{2} \mathrm{O}_{3}\right)$, gallium $(\mathrm{Ga})$, rubidium $(\mathrm{Rb})$, strontium $(\mathrm{Sr})$, Yttrium $(\mathrm{Y})$, zirconium $(\mathrm{Zr})$, niobium $(\mathrm{Nb})$, barium $(\mathrm{Ba})$, 
titanium (Ti), manganese (Mn) and/or magnesium oxide (MgO) (Ebert et al. 2015; Hughes and Fortier 2007;150-151).

The trace element impurities make each obsidian flow chemically unique, and homogenous unto itself, though a degree of intrasource chemical variation exists (Andrefsky 2005; Braswell et al. 2000). Sourcing obsidian samples thus can be carried out with high accuracy, as long as the sample size is large enough, and the source has been identified. Unfortunately, due to limited known obsidian sources in the 1970s, it was common for obsidian samples recovered during that time from Preclassic Era contexts to be listed as having unknown sources through compositional analysis (Blomster and Glascock 2011), thus requiring sources to be evidenced through other means, chiefly macroscopic and microscopic visual analysis.

Sourcing

Obsidian sourcing is

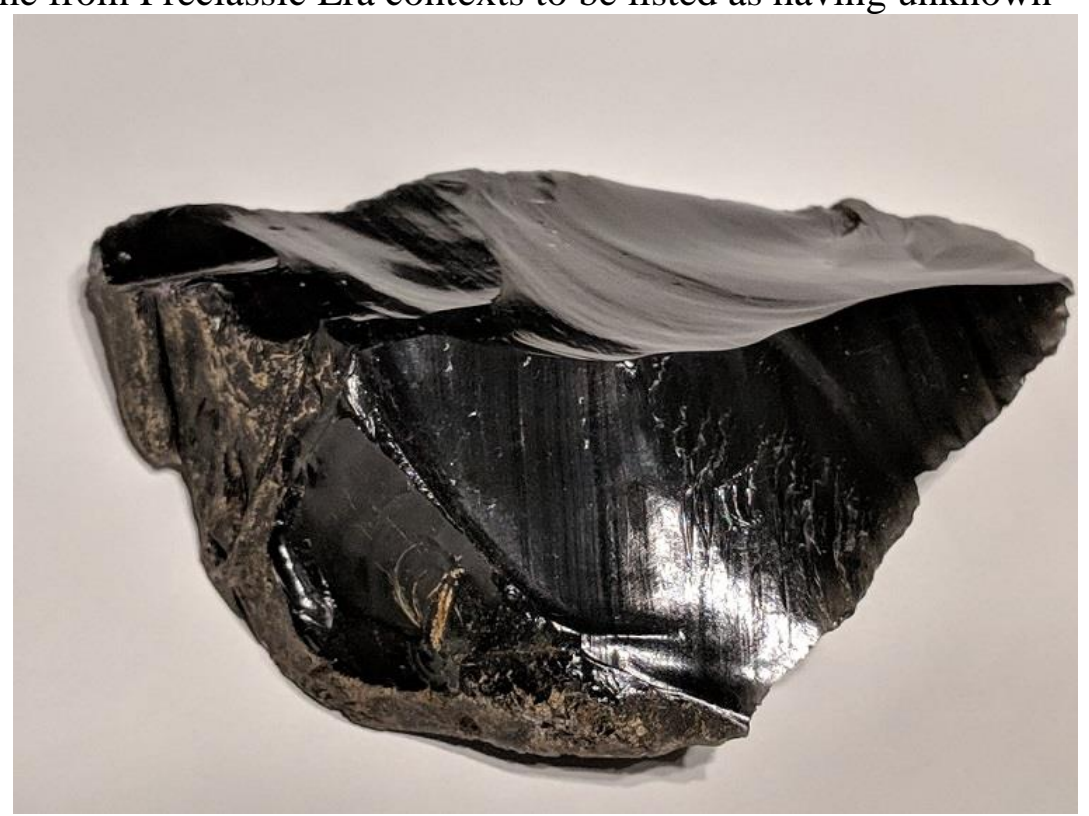
Image 1 Obsidian core fragment with cortex. (Original photo by Alex Tischler)

conducted primarily in two ways: visual analysis and compositional analysis. Visual analysis relies on sourcing samples through arbitrarily defined traits. Braswell et al. thoroughly summarized methods for visual sourcing obsidians in a 2000 paper. They outline seven optical categories for visually sourcing obsidians: "(1) the refracted color; (2) the reflected color; (3) the degree of translucence and opacity; (4) the degree to which refracted light is diffused; (5) the presence, size, color, 
frequency, and nature of inclusions; (6) the texture and luster of flaked surfaces; and (7) the color, texture, and thickness of cortex" (Braswell et al. 2000:270-271). Due to the reliance on a subjective reality and arbitrary categories, visual sourcing remains controversial. Braswell et al. point out their preferences of lighting, "Braswell favors the use of a variety of light sources, ranging from natural sunlight to fluorescent. In contrast, Clark prefers to use the same light source for consistence" (2000:271), which is echoed by Pierce who used sunlight for visual analysis (Pierce 2013). Moholy-Nagy and Nelson further argue "considerable within-source optical variability" demonstrates that visual queues are inadequate to accurately source obsidians (1990:70). Braswell et al. provide the "corpus of descriptions of the optical characteristics" which Moholy-Nagy and Nelson require (1990:70), and demonstrate that visual sourcing is necessary and reliable within a region, especially when paired with compositional analysis. Table 1 provides a break down of the visual characteristics of the three commonly used Guatemala obsidian sources by the Maya: Ixtepeque, E1 Chayal, and San Martín Jilotepeque.

Two methods of compositional analysis commonly employed are X-ray fluorescence spectrometry (XRF) and instrumental neutron activation analysis (INAA). First, XRF is a quantitative analysis of the elemental composition of a sample. By ionizing a sample with a highenergy X-ray beam, the fluorescence resulting from the dislodgement of an element's inner electron and subsequent replacement with an outer electron, can be analyzed. Each element gives off a unique wavelength which when recorded results in an overall chemical composition of the sample (Guthrie and Ferguson 2012; Wirth and Barth 2007). Energy-dispersive XRF, the most common method of XRF spectrometry used in obsidian chemical analysis, simultaneously excites all elements in a sample. Commonly used EDXRF and related onsite portable XRF (pXRF) are non-destructive methods, and requires samples to be $>10 \mathrm{~mm}$ in smallest dimension, 
and >2 mm thick (Andrefsky 2005:44); high precision XRF methods require >100mg of ground material for analysis (Shackley 2011).

The second method commonly used for compositional analysis is neutron activation analysis (NAA). The method provides a quantitative and qualitative analysis of major, minor, and trace elements. A sample is bombarded from neutron sources to destabilize the element, creating artificial radioisotopes. To test the trace elements commonly found in obsidian, delayed gamma NAA (dgNAA) is utilized. Once the sample is irradiated the excess energy of the radioisotopes is given off as gamma radiation. The gamma radiation spectrum is analyzed first a few hours after irradiation, then again 3-4 days, and once more at 4-8 weeks, which results in a multi-elemental analysis of the sample (Glascock 2017a). “Automated sample handling, gammaray measurement with solid-state detectors, and computerized data processing" makes instrumental neutron activation analysis (INAA) a viable choice for concurrently sourcing multiple elements within an obsidian sample (Glascock 2017a). INAA is a highly precise, however it can't be used to analyze as wide a range of elements as XRF, often times necessitating an overlap of analyses. A sample size of $~ 500 \mathrm{mg}$ is recommended, however sample sizes as small as 5-10 mg can be analyzed (Glascock 2017b). INAA is a destructive process, requiring samples to be cut and ground, and once the sample becomes irradiated requires special storage (Braswell et al. 2000). 
Table 1. Table recreated from Braswell 2000 Table 1 describing characteristics for visually sourcing El Chayal, Ixtepeque, and San Martín Jilotepeque.

\begin{tabular}{|c|c|c|c|c|c|c|c|}
\hline Source & Refracted Color & $\begin{array}{l}\text { Reflected } \\
\text { Color }\end{array}$ & Translucency/Opacity & Sharp/Diffused & Inclusions & $\begin{array}{c}\text { Luster and Texture of } \\
\text { Surface }\end{array}$ & Cortex \\
\hline El Chayal & $\begin{array}{c}\text { Frequently } \\
\text { medium gray } \\
\text { with milky or } \\
\text { waxy appearance, } \\
\text { thickest portion } \\
\text { often has roseate } \\
\text { hue. Less } \\
\text { commonly, clear, } \\
\text { dark gray, or } \\
\text { black. }\end{array}$ & $\begin{array}{l}\text { Medium gray to } \\
\text { black. }\end{array}$ & $\begin{array}{c}\text { Medium translucency } \\
\text { but banded portions are } \\
\text { opaque. }\end{array}$ & $\begin{array}{l}\text { Diffused light, } \\
\text { appearance } \\
\text { similar to } \\
\text { frosted glass. }\end{array}$ & $\begin{array}{l}\text { Frequent but small, } \\
\text { dark grey or black } \\
\text { banding and dusty } \\
\text { inclusions are } \\
\text { common in clearer } \\
\text { examples. When } \\
\text { present, banding is } \\
\text { wide and somewhat } \\
\text { irregular. }\end{array}$ & $\begin{array}{l}\text { Medium luster, soapstone } \\
\text { texture, fine unmarred } \\
\text { surface. }\end{array}$ & $\begin{array}{l}\text { Generally thin and } \\
\text { relatively smooth. }\end{array}$ \\
\hline Ixtepeque & $\begin{array}{l}\text { Usually brown, } \\
\text { similar in color to } \\
\text { dark sherry or } \\
\text { cola. Rare pieces } \\
\text { are completely } \\
\text { opaque. }\end{array}$ & $\begin{array}{l}\text { Black but } \\
\text { opaque pieces } \\
\text { are medium } \\
\text { gray. } \\
\text { Mahogany } \\
\text { spots are } \\
\text { frequent on } \\
\text { opaque nodules, } \\
\text { but rare on } \\
\text { artifacts. }\end{array}$ & $\begin{array}{l}\text { Most commonly } \\
\text { medium translucency, } \\
\text { but banded portions are } \\
\text { opaque. Completely } \\
\text { opaque pieces are } \\
\text { found. }\end{array}$ & $\begin{array}{l}\text { Sharp refracted } \\
\text { light, like } \\
\text { artificial glass. }\end{array}$ & $\begin{array}{l}\text { Usually none, } \\
\text { though banding } \\
\text { (typically milky gray } \\
\text { to black) is common. } \\
\text { Bands are narrow, } \\
\text { straight, and parallel. } \\
\text { Infrequently, cola- } \\
\text { colored material has } \\
\text { sand-grain-sized } \\
\text { inclusions, but dusty } \\
\text { inclusions are } \\
\text { absent. }\end{array}$ & $\begin{array}{l}\text { High luster unless opaque } \\
\text { gray which has medium } \\
\text { luster. Surface typically is } \\
\text { very smooth and glassy, } \\
\text { though pieces with sand } \\
\text { inclusions me be somewhat } \\
\text { pitted. }\end{array}$ & $\begin{array}{l}\text { Generally quite thin } \\
\text { and regular, often } \\
\text { with perlitic } \\
\text { surface. }\end{array}$ \\
\hline $\begin{array}{c}\text { San } \\
\text { Martín } \\
\text { Jilotepeque }\end{array}$ & $\begin{array}{l}\text { Usually dark gray } \\
\text { with some brown } \\
\text { hue. Highly } \\
\text { variable and } \\
\text { dependent on } \\
\text { density of } \\
\text { particulate } \\
\text { inclusions. }\end{array}$ & Black & $\begin{array}{l}\text { Low to medium, } \\
\text { irregular depending on } \\
\text { density of inclusions. }\end{array}$ & $\begin{array}{l}\text { Highly variable, } \\
\text { though } \\
\text { generally falling } \\
\text { between El } \\
\text { Chayal and } \\
\text { Ixtepeque in the } \\
\text { degree of } \\
\text { diffusion. }\end{array}$ & $\begin{array}{l}\text { Ubiquitous and of } \\
\text { all sizes from dusty } \\
\text { to sand-gran-sized } \\
\text { particles. Inclusions } \\
\text { are disturbed } \\
\text { throughout in } \\
\text { clouds, very uneven } \\
\text { black bands, and } \\
\text { other irregular } \\
\text { formations. } \\
\text { Inclusions are much } \\
\text { more dense than in } \\
\text { other two sources. } \\
\text { Some pieces have } \\
\text { irregular mahogany } \\
\text { or black spots. }\end{array}$ & $\begin{array}{l}\text { Low luster, though the surface } \\
\text { can have an oily sheen. } \\
\text { Surface is pitted due to } \\
\text { inclusions, and has an "orange } \\
\text { skin" appearance. Least } \\
\text { glassy of the three major } \\
\text { sources. }\end{array}$ & $\begin{array}{l}\text { Medium to thick, } \\
\text { often rough. }\end{array}$ \\
\hline
\end{tabular}




\section{Distribution Models}

In their 2009 paper, De León et al. examine two important questions: “(1) what does blade trade look like in the archaeological record, and (2) how can blade trade be distinguished from other potential distribution systems?" To answer these questions, they used co-author Kenneth Hirth's distribution approach (1998) to reconstruct complex forms of obsidian exchange. They proposed three distributional models for obsidian exchange: whole-blade trade, processed-blade trade, and local-blade production. Each model of trade is defined by characteristics of obsidian blades in the archaeological record. The characteristics they search for are: proximal-distal and medial-distal ratios, primary and secondary production evidence, whole prismatic-blades, and obsidian cores (Table 2). Data from previously excavated obsidian assemblages from sites spanning three regions: Basin of Mexico, Tlaxcala, and Valley of Oaxaca, were used to evaluate their models.

Table 2. Characteristics used by De León et al. (2006: Table 1) to identify obsidian distribution model.

\begin{tabular}{|c|c|c|c|c|}
\hline $\begin{array}{c}\text { Proximal-Distal } \\
\text { Ratio }\end{array}$ & Medial-Distal Ratio & $\begin{array}{c}\text { Primary } \\
\text { Production } \\
\text { Evidence }\end{array}$ & $\begin{array}{l}\text { Secondary } \\
\text { Production } \\
\text { Evidence }\end{array}$ & $\begin{array}{c}\text { Whole Prismatic } \\
\text { Blades }\end{array}$ \\
\hline $\begin{array}{l}\text { The ratio of proximal } \\
\text { to distal sections of a } \\
\text { segmented obsidian } \\
\text { prismatic blade. }\end{array}$ & $\begin{array}{l}\text { The ratio of medial } \\
\text { to distal sections of a } \\
\text { segmented obsidian } \\
\text { prismatic blade. }\end{array}$ & $\begin{array}{l}\text { - Blade cores } \\
\text { - Exhausted cores } \\
\text { - Recycled cores } \\
\text { - Rejuvenation } \\
\text { flakes } \\
\text { - Core fragments }\end{array}$ & $\begin{array}{l}\text { - Core-shaping } \\
\text { flakes } \\
\text { - Macroblades } \\
\text { - Percussion blades } \\
\text { - Early series } \\
\text { pressure blades } \\
\text { - Plunging blades } \\
\text { - Blades with hinge } \\
\text { fractures } \\
\text { - Crested blades } \\
\text { Distal orientation } \\
\text { blades } \\
\text { - Overhang removal } \\
\text { flakes }\end{array}$ & $\begin{array}{l}\text { Unsegmented } \\
\text { obsidian prismatic } \\
\text { blades }\end{array}$ \\
\hline
\end{tabular}

Blade Trade

The lithic manufacturing technique, stages of production, qualities of source obsidian core, the means of transportation, and other factors provide important information into 
reconstructing ancient political economies. These factors can be revealed by looking at the characteristics defined in Table 2 which contributes to the reconstruction of distribution models.

De León et al. define blade trade as, "the exchange of prismatic blades without cores needed to produce them" (2009:113). Prismatic cores, exhausted cores, recycled cores, rejuvenation flakes, and core fragments all make up primary production evidence, while "the by-products associated with core shaping and maintenance (core-shaping flakes, decortication blades, macroblades, percussion blades, early series pressure blades), production errors (plunging blades, blades with hinge fractures), and the correction of production errors (crested blades, distal orientation blades, overhang removal flakes)" make up secondary production evidence (De León et al. 2009:114). Because obsidian was a rare material De León et al. suggested crafters would have kept cores in their possession, meaning the presence of primary and/or

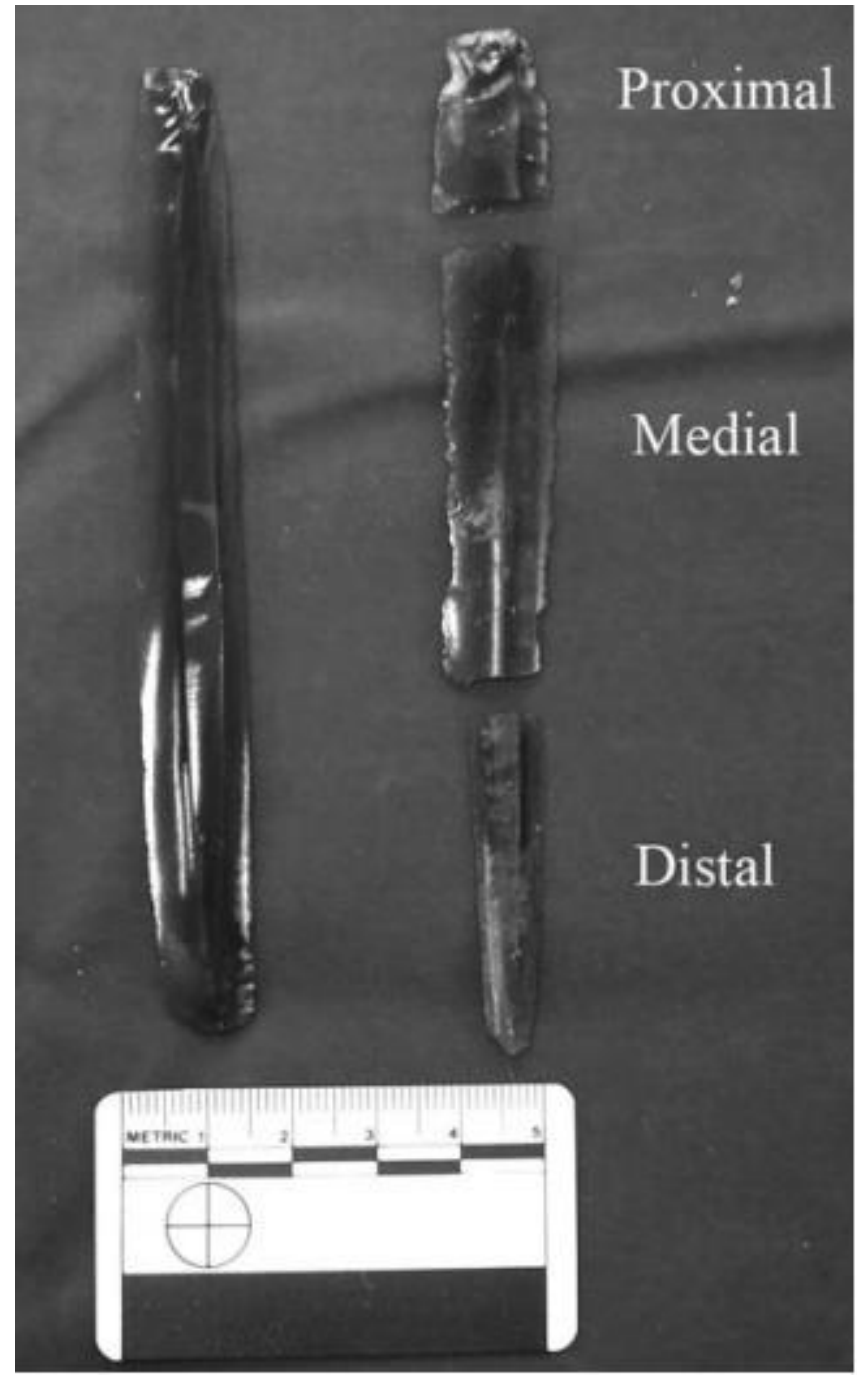

Image 2. A whole obsidian prismatic blade and a blade segmented into proximal, medial, and distal ends. (Originally found in DeLeon et al. 2009:Figure 6) secondary production evidence would indicate local production $(2009: 119)$

Similarly, based on the physical properties of obsidian, the presence of whole and segmented prismatic blades reveals important distribution information. As mentioned, obsidian 
breaks in a relatively predictable manner. A prismatic blade typically produces one proximalplatform edge — segment, at least one medial—middle—segment, and one distal—tip opposite the proximal — segment which often curves. Based on these characteristics, a prismatic blade is expected to optimally produce a proximal-medial-distal segment ratio of 1:1:1, however this is not expected at sites. Besides being the smallest segment, the curve in the distal segment is less likely to appear in the record for two reasons. First, severe curves require a high degree of flintknapping skill to properly implement. Second, the curve increases risks of blades breaking in transportation. By segmenting the distal tip, the blades are more likely to survive long journeys. A third factor to consider is the possibility that one large prismatic blade "can produce many usable medial segments, such segments often dominate blade assemblages" (De León et al. 2009). A complete breakdown of the models to follow can be found in Table 3.

Whole-Blade Trade Model

The whole-blade trade model "assumes that complete blades were exchanged without a corresponding trade in obsidian cores" (De León et al. 2009). Under this model, blades would have been produced in one location, and distributed whole in a separate location. Because prismatic blades would have been broken down on site, with the medial being processed into multiple usable segments, they'd produce a proximal-distal ratio of 1:1 and a medial-distal of 23:1, and no primary or secondary evidence.

Processed-Blade Trade Model

Under this model prismatic blades were processed—severely curved distal (and sometimes proximal) end removed — before being transported from production site to receiver. Removal of the distal end flattened the blade, decreasing the likelihood of blades breaking during transportation. The loss of the distal segment "does not generally reduce a blade's overall utility 
or desirability because curved segments are both difficult to haft and a poor choice for straight edge cutting" (De León et al. 2009:118). Due to the removal of the distal end, at sites receiving processed blades the expected proximal-distal ratio is $6: 1$, and medial-distal would be similarly high at 6:1. As with whole-blade trade, processed-blade trade is not associated with primary or secondary production evidence.

Local-Blade Production Model

Under local-blade production, blade cores were brought in locally, with blade production carried out onsite by itinerant crafters - travelers bringing their skills and supplies where needed - or by local crafters living permanently in the region. The authors acknowledge distinguishing between local and itinerant production could be challenging, they do provide a key difference. Itinerant crafting is expected to produce segment ratios similar to whole-blade trade, found in association with secondary production evidence, but limited primary evidence due to cores remaining in the crafter's possession (De León et al. 2009). Local crafting production is expected to have similar characteristics as itinerant crafting, but also include primary production evidence and more varied forms of secondary production evidence due to all stages of production happening onsite. 


\begin{tabular}{lccccc}
\hline Table 3. Models of distribution with expected associated evidence. & & & \\
\hline \multicolumn{1}{c}{ Model } & $\begin{array}{c}\text { Primary } \\
\text { Production } \\
\text { Evidence }\end{array}$ & $\begin{array}{c}\text { Secondary } \\
\text { Production } \\
\text { Evidence }\end{array}$ & $\begin{array}{c}\text { Whole } \\
\text { Blades } \\
\text { Present }\end{array}$ & $\begin{array}{c}\text { Proximal- } \\
\text { Distal } \\
\text { Ratio }\end{array}$ & $\begin{array}{c}\text { Medial- } \\
\text { Distal } \\
\text { Ratio }\end{array}$ \\
\hline \hline Whole-blade trade & No & No & Yes & $1: 1$ & $2-3: 1$ \\
Processed-blade trade & No & No & No & $6: 1$ & $6: 1$ \\
$\begin{array}{l}\text { Local-blade production } \\
- \text { Local Crafter }\end{array}$ & No & Yes & Yes & $1: 1$ & $2-3: 1$ \\
$\begin{array}{l}\text { Local-blade production } \\
\text { - Itinerant Crafter }\end{array}$ & Yes & Yes & Yes & $1: 1$ & $2-3: 1$ \\
\hline
\end{tabular}

Sites

Sites were selected by a simple yet specific criteria: 1) falls within the Maya regions; 2) Maya occupations during the Preclassic; 3) prismatic obsidian blades from Preclassic contexts were recovered; and 4) obsidian assemblages have a sample size of over 20 blade segments. Furthermore, in sifting through data from excavation projects, I searched for sites where the investigators provided breakdown of prismatic blade sections - proximal, medial, and distal. This does reveal a few complications. A common architectural trend among the Maya was building over existing sites, thus burying the oldest settlements. Preclassic contexts at Maya sites which were occupied from Preclassic to Classic or later are often locked under larger and recent Classic architecture. A second complication arises not with Maya architecture, but with archaeological reporting. As De León et al. noted, "Unfortunately researchers often fail to distinguish between proximal, medial, and distal blade segments or do not clarify the criteria used to identify segments in published reports (e.g., whether a distal section needs the tip or a proximal section needs the platform to be classified as such)" (2009:115). Though obsidian is found at dozens of Maya sites, it is not always the focus of research papers and analysis is sometimes limited to solely sourcing. 
Four sites met the above criteria and were chosen to evaluate De León et al.'s models: a workshop in the large city of El Ceibal, the prominent planned city Tikal, and the ritual cave Actun Uayazba Kab, all in the Southern Lowlands; and in the Northern Lowlands, the small and underdeveloped settlement, Xtobo (see Map 1 for site locations). The Southern Lowlands were overrepresented in this analysis, while the Maya Highlands weren't represented at all, this was an unfortunate byproduct of limited sites matching the required criteria.

\section{El Ceibal}

El Ceibal has been extensively excavated, first by Harvard University’s 1960s Seibal Archaeological Project, and then by the Ceibal-Petexbatun Archaeological Project in 2005 and 2014. "The lowland Maya city of Ceibal was the largest of all the Pasión River drainage sites, both in terms of extent and in terms of total construction volume of its major public structures" (Aoyama et al. 2017:408). Pyramid-platforms were constructed across a series of hills, with Ceibal's main development located at Group A, the Central Plaza; Group C; and Group D, a fortress and ceremonial center (Aoyama et al. 2017; Aoyama 2017a; Aoyama 2017b). Ceibal's first pyramid-platform and public plaza was constructed during the early Middle Preclassic's Early-Xe phase (1000-700 B.C.E) (Table 4). During the late Middle Preclassic Escoba-Mamom phase (700-350 B.C.E), numerous stelae were constructed (Aoyama et al. 2017). A steadily increasing population and growing access to distribution networks which granted access to rare materials and access to intercultural networks of shared ideas and iconography is seen as evidence of El Ceibal's growing social hierarchy during its Middle Preclassic (Aoyama et al. 2017; Aoyama 2017a). "Ceibal reached its first peak during the Late Preclassic ContutseChicanel phase (250-100 B.C.)" (Aoyama 2017a). 
Map 1. Lowland and Highland Maya sites evaluated in this paper.

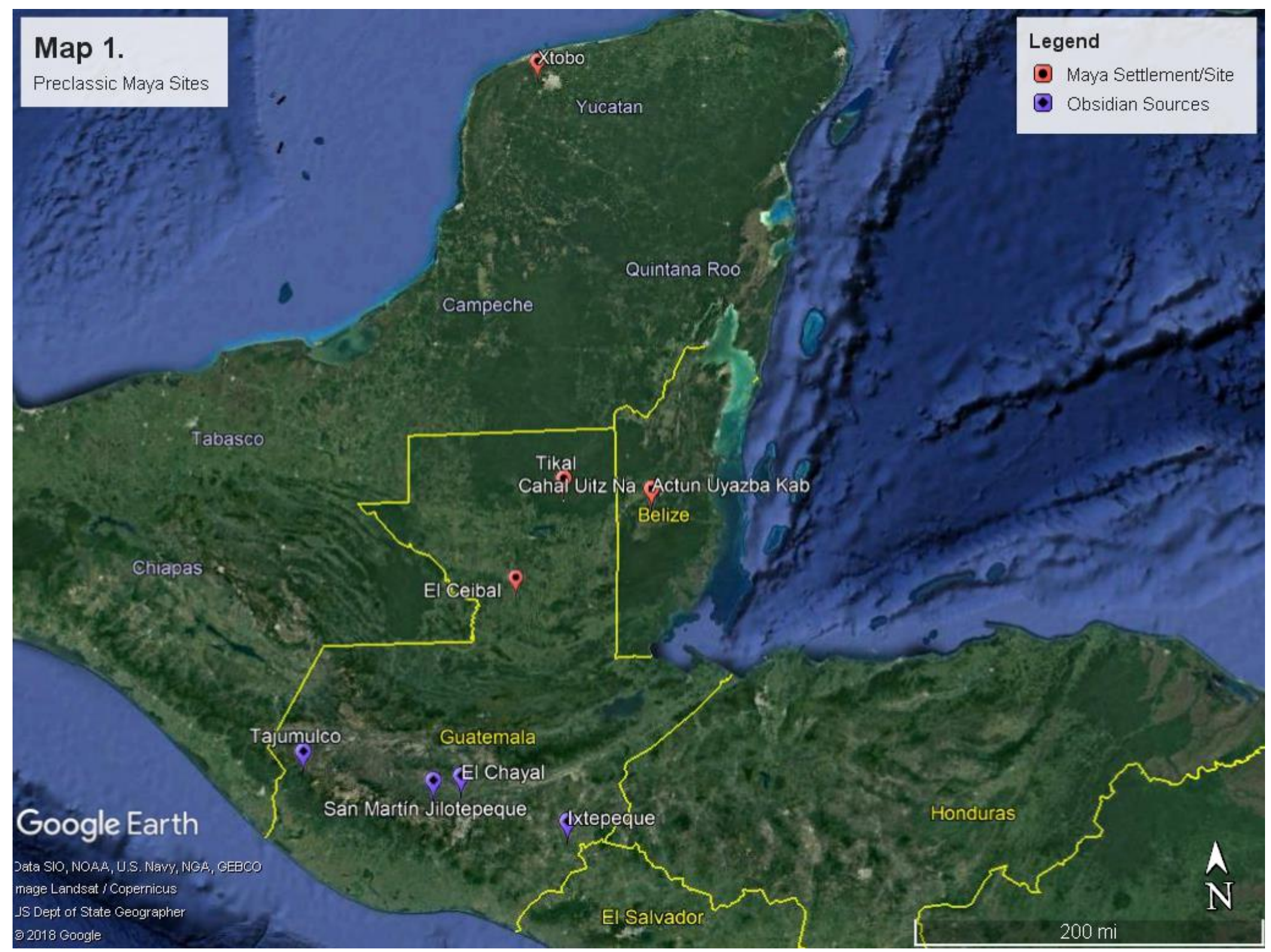


Across the excavations of Ceibal and neighboring Caobal in 2005 and 2014, The CeibalPetexbatun Archaeological Project recovered 72, 490 lithic artifacts, of which 32,473 chipped stone-predominately chert and obsidian—artifacts come from unmixed Preclassic contexts (Aoyama 2017a). While chert was available locally near the Pasión River, obsidian needed to be imported. The archaeological record for Ceibal and other excavated sites show obsidian utilization during the Preclassic underwent a diachronic change in source access and state obsidian arrived in between three Guatemalan sources. During the early Middle Preclassic, El Chayal was the dominant source, while San Martín Jilotepeque became the main source during the late Middle Preclassic to Terminal Preclassic. Ixtepeque was used in low quantities during the Preclassic (Aoyama 2017a). Ceibal had greater access to a variety of obsidian than did neighboring centers within Ceibal's influence.

Tikal

The Southern Lowland city of Tikal is considered "one of the most important Late Preclassic and Classic period settlements" (Moholy-Nagy 1999:300). In 1994, Moholy-Nagy recorded 9,900 obsidian artifacts recovered from Tikal, along with 57,000 fragments of debitage (1994:67), and “over 1,200 mostly fragmentary artifacts were recorded from Late Preclassic through Early Postclassic contexts by the University of Pennsylvania Museum's Tikal Project (195S1970) and the government of Guatemala's Proyecto Nacional de Tikal (PNT) (1979-1984)" (Moholy-Nagy 1999:300).

Located in the Southern Maya Lowlands, Tikal was founded between limestone ridges, and built up on hills in a fertile swamp. Though Tikal was the "heart of the Southern Maya Lowlands" it was also "the last area to be settled by pottery-using agriculturalists" (Moholy- 
Nagy 1994:30). There is evidence of early occupation as late as 1000 B.C.E., but Tikal wasn't permanently settled until the early Middle Preclassic (800 B.C.E.). Teotihuacan The immediate access to long-distance distribution networks evidenced by imported domestic and eccentrics, connecting Tikal with central Mexico and the Guatemalan Highlands, may indicate that Tikal was founded by an established chiefdom (Moholy-Nagy 1994:31). Even though Tikal had access to these networks, the settlement was surpassed in size and influence by nearby cities such as El Mirador during the Preclassic.

Tikal's ceramic culture defines five phases (Table 4). Two Middle Preclassic phases: the early, Eb (800 B.C.E - 600 B.C.E), and a late Tzec (600 B.C.E - 350 B.C.E.). Likewise, the Late Preclassic is represented by two phases: the Chuen phase between 350 B.C.E to 1 C.E. and the Cauac phase spanning 1 C.E. to 150 C.E. The final phase is a transitional, Terminal Preclassic (overlaps with Moholy-Nagy’s Protoclassic) phase, Cimi from 150 C.E. to 250 C.E. (MoholyNagy 1999:301).

Xtobo

Nestled in the far northwest Yucatan, Xtobo was a recent discovery. Started in 1999 and spanning four field seasons, the Proyecto Costa Maya (PCM) performed a regional survey revealing 140 Preclassic sites in the Northern Lowlands, including Xtobo (Anderson 2011:302). PCM surveyed and excavated three test pits in 2002, and David Anderson inaugurated the Proyecto Arqueológico de Xtobo (PAX) in 2004. Also spanning four field seasons PAX excavated 67 ha, including the site center, and "recording 387 structures, 116 metates, 12 pozos (ground-water wells), and two caves" and a ballcourt (Anderson 2011:302). 
Table 4. Preclassic cultural phases for sites.

\begin{tabular}{|c|c|c|c|c|}
\hline Phase & El Ceibal & Tikal & Xtobo & Actun Uayazba Kab \\
\hline Middle Preclassic & $\begin{array}{l}\text { Xe } \\
(1000 \text { - } 700 \text { B.C.E. })\end{array}$ & $\begin{array}{l}\text { Eb } \\
(800-600 \text { B.C.E. })\end{array}$ & $\begin{array}{l}\text { Nabanche } 1 \& 2 \\
(800 \text { - } 400 \text { B.C.E. })\end{array}$ & \\
\hline Middle Preclassic & $\begin{array}{l}\text { Escoba-Mamom } \\
\text { (700 - } 350 \text { B.C.E.) }\end{array}$ & $\begin{array}{l}\text { Tzec } \\
\text { (600 - } 350 \text { B.C.E.) }\end{array}$ & $\mathrm{Am}$ & \\
\hline Late Preclassic & & $\begin{array}{l}\text { Chuen } \\
\text { (350 B.C.E - } 1 \text { C.E. }\end{array}$ & Beech & \\
\hline Late Preclassic & $\begin{array}{l}\text { Contutse-Chicanel } \\
(250 \text { - } 100 \text { B.C.E.) }\end{array}$ & $\begin{array}{l}\text { Cauc } \\
\text { (1 C.E. - } 150 \text { C.E.) }\end{array}$ & & Sierra Red \\
\hline Terminal Preclassic & & $\begin{array}{l}\text { Cimi } \\
\text { (150 C.E. - } 250 \text { C.E.) }\end{array}$ & & Aquacate Orange \\
\hline
\end{tabular}


Xtobo was located "far from known centers of major Middle Preclassic cultural development," resulting in a "small, but sophisticated, site" (Anderson 2005:2). Common among Maya settlements, Xtobo was laid out around an "elite-ceremonial core" (Anderson 2011:307). To the north and east are two $8 \mathrm{~m}$ tall pyramids, and to the south and west smaller platforms defining the inner plaza (Anderson 2011:304). Radiating from the core plaza were five sacbes, three-Chikin, Xaman, and Chaltun--led to large elite residential complexes, Sacbe Jo' to a partially deconstructed third pyramid, and the most prominent sacbe, Nohol, led to a double Triadic Group structure (Anderson 2011:304, 307). Three other Triadic Group structures were discovered. Sacbe Nohol connected to the southern closing mound of the ballcourt, with stairs cut into both the ballcourt's playing alley and plaza sides, which created a long pathway into the central plaza. The majority of structures excavated were part of a "dense residential settlement" outside the elite-ceremonial core (Anderson 2011:307). To the northwest of the core was a series of sacbe-esque structures aligned in a roughly circular pattern covering 5 ha. This structure pattern is unique to Xtobo and dubbed the Xtaabay Group, though purpose is still unknown (Anderson 2011:308).

Xtobo's assemblage consists of 10,012 pottery sherds, 30 lithics — 17 obsidian segmented prismatic blades, two quartz manuport, and 11 chert artifacts — and 68 marine shell manuports. Though no material was dated, Anderson suggests a relatively brief occupation during the Preclassic "lasting no more than a few hundred years" (Anderson 2011:313). Site occupation roughly dates from Middle Preclassic to Late or Terminal Preclassic, with brief reoccupations during Classic and Postclassic eras based two Classic structures and assemblages (Anderson 2011:313). Ceramic sherds from the Mamom and Chicanel spheres of the overlapping Am Ceramic and Beech Ceramic Complexes (Middle and Late Classic periods) make up 60\% of the 
identified pottery (Anderson 2010:268,503; Anderson 2011:312). Additionally, the obsidian prismatic blades lend support for Middle and Late Preclassic occupation. The majority of the blades were sourced to El Chayal favored across Maya regions during the Late Preclassic, two were sourced to San Martín Jilotepeque utilized predominately during the Middle Preclassic, one broadly of Guatemalan origin, and one from either Ucareo or Saragosa in central Mexico (Anderson 2011:313). The Triadic Group architecture was favored during the Middle and Late Preclassic, being replaced by the Classic periods.

Considering its short occupation, Xtobo appears to have been carefully planned with its "well-organized plaza" and efficient pathing (Anderson 2011:303). Despite being considered underdeveloped in comparison to other Middle Preclassic sites (Anderson 2005), its sophistication could be indication of its settlement by an already established chiefdom in the area. This is further reflected by immediate access to far-reaching trade networks for material and cultural goods, such as marine shells and central Mexican obsidian. Anderson proposed Xtobo had a population of 1,550 residents during its Preclassic based on number of residential structures excavated, and a structure density of 5.8 structures per hectare; this is identical to neighboring Komchen which had a similar occupation timeframe (Anderson 2011:308).

The PAX excavation encountered material culture and structures up to the site boundaries, so the extent of Xtobo's geographical footprint is still unknown. To date, PAX has been the only excavation of Xtobo.

\section{Actun Uayazba Kab}

Actun Uayazba Kab ("Cave of the Handprints") is a cave in the Roaring Creek Valley of the Cayo District of Belize utilized by the Maya for ritual bloodletting (Griffith 1999a:85; Stemp et al. 2018). The site was first reconnoitered in 1996 by Cameron Griffith, and later investigated 
during the 1997-1998 seasons of the Western Belize Region Cave Project (Griffith 1999a: 8586). The nearest known surface site to Actun Uayazba Kab is Cahal Uitz Na 605 m to the east; another two caves, Actun Tunichil Muknal and Actun Nak Beh, are located nearby (Conlon and Ehret 1999a:37).

The $18 \mathrm{~m}$ tall east-facing entrance, separated by a seven-meter wide column, leads into Uayazba Kab reveal (Griffith 1999a:86). There are five chambers branching off from the interconnected entrance, and a ledge above entrance 1 with seven travertine pools. Material culture recovered in the cave and pools indicate light usage began in the Late or Terminal Preclassic, peaked during the Classic before collapsing during the Terminal Classic; sparse usage occurred during the Postclassic (Stemp et al. 2018:10). Though the cave had previously been looted (Griffith 1999a:99; Ferguson and Gibbs 1999:114), material evidence still indicated possible ritually specific "dark" and "light" zones within the cave. The light zones of the entrance features rock formations "carved intro petroglyphs, depicting crudes faces, footrprints, elaborate designs, and anthropomorphic figures" (Stemp et al. 2018:9); all ceramic sherds were recovered from light zones. Dark zones feature pictographs of handprints, triangles, and simple charcoal left from torch tamping (Stemp et al. 2018:10; Griffith 1999a:95). Other material culture recovered included imported slate stones, conch shell fragments, chert tools and debitage, 113 obsidian artifacts from Late Preclassic to Late Classic contexts, and one green obsidian eccentric. (Stemp et al. 2019:9; Griffith 1999a; Ferguson and Gibbs 1999; Wrobel et al. 2017). 11 human remains were also recovered from alcoves in the cave. The high number of obsidian blades have been used to argue that the trio of caves were used for self-sacrificial bloodletting rituals (Stemp et al. 2018; Griffith 1999b). 
The central core of nearby surface site, Cahal Uitz Na, is spread across six plazas, covering an area of 22,482 square meters (Conlon and Ehret 1999:38). Earliest known construction at the core, including as ballcourt, is dated to the Late Preclassic (Hodgman 2001:3; Ferguson 1999: 48,51). Occupation occurred through to the Terminal Classic. Uitz Na's layout alludes to an affinity for ritual cave usage, seen both in the settlement of a site close to three cave systems (Conlon and Ehret 1999:37), a 230-meter sacbe extending from Uitz Na's southside south towards Actun Nak Beh (Hodgman 2001 3, 22; Conlon and Ehret 1999:38), and material culture found in Actun Tunichil Muknal, Actun Nak Beh, and Actun Uayazba Kab.

\section{Results}

\section{El Ceibal}

Two exhausted polyhedral cores dated to Ceibal's early Middle Preclassic were recovered, with samples analyzed through XRF showing El Chayal as the predominant source for obsidian. There was a substantial increase in obsidian production during the Late Middle Preclassic along with a shift to reliance on San Martín Jilotepeque obsidian. Late Middle Preclassic contexts produced, 11 complete and two near complete initial pressure blades, and five complete and four nearly complete prismatic blades, and 33 exhausted polyhedral cores made up the primary production evidence. There was a decline in obsidian consumption during the Late Preclassic. Only one whole initial pressure blade, one exhausted polyhedral core, and one recycled exhausted polyhedral core were recovered. This decline continued into the Terminal Preclassic; one exhausted and one recycled exhausted polyhedral core were recovered (see Table 5). The presence of an obsidian crafters' workshop and associated debitage from the early Middle Preclassic found within Ceibal confirms that local production was occurring. 
Tikal

While just under a thousand obsidian artifacts, the majority prismatic blades, are from Preclassic contexts, a lack of nuanced reporting of Tikal obsidian prismatic blade segments has prevented an analysis of the proximal-medial and medial-distal ratios. Furthermore, previous indepth analyses have looked at obsidian trends broadly across phases, rarely taking into account of diachronic changes in distribution, and focus on trying to accurately source Tikal's extensive access to obsidians (Moholy-Nagy and Nelson 1990; Moholy-Nagy 1994, 1999). Tikal still stands as an important site with a rich material culture history of long-distance distribution networks, importing distinct golden-green obsidians from the central Mexican Pachuca sources, chiefly Cerro Las Navajas, along with all Guatemalean Highland obsidians, San Martín Jilotepeque, El Chayal, and Ixtepeque, during late Middle Preclassic (Moholy-Nagy and Nelson 1990:76, 1999:305).

In a compositional analysis of 64 obsidian artifacts, 12 came from Late Classic contexts. This analysis included obsidian from the all Highland Guatemalan sources. One prismatic blade, two exterior blade flakes, one cortical flake, and one unidentifiable piece of obsidian were sourced to El Chayal. San Martín Jilotepeque is represented by five prismatic blades and one cortical flake. Finally, a single blade core was sourced to Ixtepeque (see Table 6) (Moholy-Nagy and Nelson 1990:76).

Notably, 580 "thin bifaced" stemmed projectile points stemless knives were recovered from Tikal ranging from Late Preclassic to Classic contexts (Moholy-Nagy 1999:304). MoloyNagy assigns these thin bifaces to Spence's Stemmed Biface A types found at Teotuhuacan. Of the cross-phase contexts, 128 (31\%) were of central Mexican sources, Pachuca making up 171 of those; two were chemically sourced to Ixtepeque. Unfortunately, Moholy-Nagy did not breakup 
up the quantities by phase, they are reportedly found in Late Preclassic, and mixed Late Preclassic and Early Classic contexts.

Xtobo

The PAX excavation recovered 17 obsidian prismatic blade segments sourced to Middle and Late Preclassic contexts, though one was discovered in a test pit of mixed Late Preclassic and Classic contexts (see Table 7). All blades were visually sourced. 13 of the blades were sourced to El Chayal in the Guatemalan Highlands, two blades were sourced to be from San Martín Jilotepeque, one blade sourced broadly to Guatemala, and one blade to either the Ucareo or Saragosa source in central Mexico. Seventeen blade segments is a small sample size for the purpose of analysis, and the collection has been grouped into a single "Preclassic" context. No primary or secondary production evidence was discovered with the blades. It should be noted that no primary or secondary production evidence was discovered for chert or quartz lithics either despite chert being an abundant local resource.

\section{Actun Uayazba Kab}

While Classic contexts extend beyond the scope of this paper, the entire Late Preclassic to Late Classic obsidian assemblage was chosen to enhance sample size. Save for an increase in importation there exists no reported diachronic change in obsidian assemblages at Uayazba Kab between the Late Preclassic and Late Classic (Stemp et al. 2018). From the caves and exterior pools of Actun Uayazba Kab, 109 third-series segmented obsidian prismatic blades and two whole third-series prismatic blades were recovered from Late or Terminal Preclassic to Late Classic contexts, along with two whole percussion blades (see Table 8). Based on visual sourcing, El Chayal was the most represented source site at 97 of the obsidian artifacts, followed by Ixtepeque at 12 blades, and only one blade segment sourced to San Martín Jilotepeque; three 
were undetermined (Stemp et al. 2018:11). Stemp and coauthors identify 100 of the blades or segments as being third-series prismatic blades based on the presence of two or more dorsal ridges. Additionally, none of the lithics had cortex. (Stemp et al. 2018:11) 
Table 5. Breakdown of obsidian artifacts recovered form Ceibal between early Middle Preclassic to Terminal Preclassic.

\begin{tabular}{|c|c|c|c|c|c|c|c|c|c|c|}
\hline Time & $\begin{array}{c}\text { Primary Production } \\
\text { Evidence }\end{array}$ & $\begin{array}{l}\text { Secondary } \\
\text { Production } \\
\text { Evidence }\end{array}$ & $\begin{array}{c}\text { Whole } \\
\text { Prismatic } \\
\text { Blades }\end{array}$ & $\begin{array}{l}\text { Prismatic } \\
\text { Blade } \\
\text { Segment } \\
\text { Quantity }\end{array}$ & $\begin{array}{c}\text { Prismatic } \\
\text { Segment } \\
\text { Proximal- } \\
\text { Distal } \\
\text { Ratio }\end{array}$ & $\begin{array}{c}\text { Prismatic } \\
\text { Segment } \\
\text { Medial- } \\
\text { Distal } \\
\text { Ratio }\end{array}$ & $\begin{array}{l}\text { Initial } \\
\text { Blade } \\
\text { Segment } \\
\text { Quantity }\end{array}$ & $\begin{array}{l}\text { Whole } \\
\text { Initial } \\
\text { Blades }\end{array}$ & $\begin{array}{c}\text { Initial } \\
\text { Proximal- } \\
\text { Distal } \\
\text { Ratio }\end{array}$ & $\begin{array}{c}\text { Initial } \\
\text { Medial- } \\
\text { Distal } \\
\text { Ratio }\end{array}$ \\
\hline $\begin{array}{l}\text { Early } \\
\text { Middle } \\
\text { Preclassic }\end{array}$ & $\begin{array}{l}\text { - Two exhausted } \\
\text { cores } \\
\text { - One platform } \\
\text { rejuvenation flake }\end{array}$ & 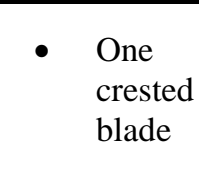 & 0 & 60 & $5.7: 1$ & $13.3: 1$ & 15 & 0 & $5: 0$ & $10: 0$ \\
\hline $\begin{array}{l}\text { Late } \\
\text { Middle } \\
\text { Preclassic }\end{array}$ & $\begin{array}{l}\text { - } 33 \text { exhausted } \\
\text { cores }\end{array}$ & $\begin{array}{l}-86 \\
\text { crested } \\
\text { blades }\end{array}$ & 5 & 1374 & $2.7: 1$ & $6.4: 1$ & 653 & 11 & 4.1:1 & $4.9: 1$ \\
\hline $\begin{array}{l}\text { Late } \\
\text { Preclassic }\end{array}$ & $\begin{array}{l}\text { - One exhausted } \\
\text { core } \\
\text { - One recycled core }\end{array}$ & $\begin{array}{l}\text { - Eight } \\
\text { crested } \\
\text { blades }\end{array}$ & 0 & 210 & $20: 0$ & 190:0 & 69 & 1 & $8.5: 1$ & $7.75: 1$ \\
\hline $\begin{array}{l}\text { Terminal } \\
\text { Preclassic }\end{array}$ & $\begin{array}{l}\text { - One exhausted } \\
\text { core } \\
\text { - One recycled core }\end{array}$ & $\begin{array}{l}\text { Four } \\
\text { crested } \\
\text { blades }\end{array}$ & 0 & 142 & $4.3: 1$ & $10.5: 1$ & 39 & 0 & 2.4-1 & $4.4: 1$ \\
\hline
\end{tabular}




\begin{tabular}{|c|c|c|c|c|c|c|c|c|}
\hline Time & $\begin{array}{c}\text { Primary Production } \\
\text { Evidence }\end{array}$ & $\begin{array}{c}\text { Secondary } \\
\text { Production } \\
\text { Evidence }\end{array}$ & $\begin{array}{c}\text { Whole } \\
\text { Prismatic } \\
\text { Blades }\end{array}$ & $\begin{array}{c}\text { Prismatic } \\
\text { Proximal- } \\
\text { Distal } \\
\text { Ratio } \\
\end{array}$ & $\begin{array}{c}\text { Prismatic } \\
\text { Medial- } \\
\text { Distal } \\
\text { Ratio } \\
\end{array}$ & $\begin{array}{l}\text { Whole } \\
\text { Initial } \\
\text { Blades }\end{array}$ & $\begin{array}{c}\text { Initial } \\
\text { Proximal- } \\
\text { Distal } \\
\text { Ratio }\end{array}$ & $\begin{array}{c}\text { Initial } \\
\text { Medial- } \\
\text { Distal } \\
\text { Ratio }\end{array}$ \\
\hline Late Preclassic & - One blade core & $\begin{array}{l}\text { - Two exterior } \\
\text { flakes } \\
\text { - Three cortical } \\
\text { flakes }\end{array}$ & 6 & 0 & 0 & 0 & 0 & \\
\hline
\end{tabular}

Table 7. Breakdown of obsidian artifacts recovered form Xtobo between early Middle Preclassic to Terminal Preclassic (Anderson 2018).

\begin{tabular}{|c|c|c|c|c|c|c|c|c|c|c|}
\hline Time & $\begin{array}{c}\text { Primary Production } \\
\text { Evidence }\end{array}$ & $\begin{array}{c}\text { Secondary } \\
\text { Production } \\
\text { Evidence }\end{array}$ & $\begin{array}{c}\text { Whole } \\
\text { Prismatic } \\
\text { Blades }\end{array}$ & $\begin{array}{c}\text { Prismatic } \\
\text { Blade } \\
\text { Segment } \\
\text { Quantity }\end{array}$ & $\begin{array}{c}\text { Prismatic } \\
\text { Segment } \\
\text { Proximal- } \\
\text { Distal } \\
\text { Ratio }\end{array}$ & $\begin{array}{c}\text { Prismatic } \\
\text { Segment } \\
\text { Medial- } \\
\text { Distal } \\
\text { Ratio }\end{array}$ & $\begin{array}{c}\text { Initial } \\
\text { Blade } \\
\text { Segment } \\
\text { Quantity }\end{array}$ & $\begin{array}{l}\text { Whole } \\
\text { Initial } \\
\text { Blades }\end{array}$ & $\begin{array}{c}\text { Initial } \\
\text { Proximal- } \\
\text { Distal } \\
\text { Ratio }\end{array}$ & $\begin{array}{r}\text { Initial } \\
\text { Medial- } \\
\text { Distal } \\
\text { Ratio }\end{array}$ \\
\hline $\begin{array}{l}\text { Middle } \\
\text { Preclassic } \\
\text { to Terminal } \\
\text { Classic }\end{array}$ & 0 & 0 & 0 & 17 & $0.8: 1$ & $1.6: 1$ & 0 & 0 & 0 & 0 \\
\hline
\end{tabular}


Table 8. Breakdown of obsidian artifacts recovered form Actun Uayazba Kab between Late Preclassic to Late Classic (Stemp et al. 2019).

\begin{tabular}{|c|c|c|c|c|c|c|c|c|c|c|}
\hline Time & $\begin{array}{c}\text { Primary Production } \\
\text { Evidence }\end{array}$ & $\begin{array}{c}\text { Secondary } \\
\text { Production } \\
\text { Evidence }\end{array}$ & $\begin{array}{c}\text { Whole } \\
\text { Prismatic } \\
\text { Blades }\end{array}$ & $\begin{array}{l}\text { Prismatic } \\
\text { Blade } \\
\text { Segment } \\
\text { Quantity }\end{array}$ & $\begin{array}{c}\text { Prismatic } \\
\text { Segment } \\
\text { Proximal- } \\
\text { Distal } \\
\text { Ratio }\end{array}$ & $\begin{array}{c}\text { Prismatic } \\
\text { Segment } \\
\text { Medial- } \\
\text { Distal } \\
\text { Ratio } \\
\end{array}$ & $\begin{array}{c}\text { Initial } \\
\text { Blade } \\
\text { Segment } \\
\text { Quantity }\end{array}$ & $\begin{array}{l}\text { Whole } \\
\text { Initial } \\
\text { Blades }\end{array}$ & $\begin{array}{c}\text { Initial } \\
\text { Proximal- } \\
\text { Distal } \\
\text { Ratio }\end{array}$ & $\begin{array}{c}\text { Initial } \\
\text { Medial- } \\
\text { Distal } \\
\text { Ratio }\end{array}$ \\
\hline $\begin{array}{l}\text { Late } \\
\text { Preclassic } \\
\text { to Late } \\
\text { Classic }\end{array}$ & 0 & $\begin{array}{l}\text { - Two pressure } \\
\text { blades }\end{array}$ & 2 & 109 & $4.1: 1$ & $10.4: 1$ & 0 & 0 & 0 & 0 \\
\hline
\end{tabular}




\section{Discussion}

\section{Evidence of Local-Blade Production}

The discovery of an obsidian workshop at Ceibal is definitive evidence of local-blade production, providing an opportunity to validate De León et al.'s local-production model against a site where it was known to occur. While the ratios for prismatic blades don't fall within the local-blade production model of 1:1 and 2-3:1, as expected for local production, De León et al. ran into a similar issue for the small village of Tetel which they claim also locally produced prismatic blades. They calculated Late Tlatempa phase (700-600 B.C.E) proximal-distal ratio as 6:1 and medial-distal to $12: 1$, while the Texoloc phase (600-400 B.C.E) had a proximal-distal ratio of 1.8:1 and medial-distal ratio of 3.8:1 and recovered primary production evidence. De León et al. admit,

"Although the medial-distal ratio is slightly higher than what we expected for the local production model, the proximal-distal ratio, the presence of a whole blade, some primary production evidence, and the abundance of secondary production evidence conform to what we might expect for local or itinerant craftsmen production. The increase in the number of medial segments per distal segment may simply be the result of local attempts to extract more usable tool segments per blade.” (2009:124).

My ratios calculated from Aoyama et al.'s data reveal a similar pattern. An explanation for this can be found in the scarcity of obsidian in lowland Maya. Due to lowland peoples importing obsidian from highland Guatemalan sources, local crafters may have maximized the number of blades removed from cores, as evidenced by the small and masterfully exhausted cores also recovered. The workshop demonstrates this 
level of skill existed within Ceibal. Furthermore, the abundance of primary production evidence and secondary production evidence, along with the obsidian workshop, is evident that local-blade production was carried out by local flintknappers.

A second site where local-blade production possibly occurred during the Preclassic is Xtobo. While the obsidian prismatic blade segments recovered from Xtobo's Preclassic are limited, the ratios do indicate local production could have been occurring. With a proximal-distal ratio of $0.8: 1$ and medial-distal ratio of 1.6:1, this falls close to expected ratios for local or itinerant production. However, the lack of primary or secondary production evidence, along with the small sample of recovered prismatic blade segments complicate this interpretation. PAX lead David Anderson made the observation, “As no obsidian waste flakes or blade cores were recovered, obsidian prismatic blades may have been imported already manufactured, or an onsite manufacturing location has yet to be discovered. This latter explanation may also explain the general lack of chert tools" (Anderson 2011:311).

Xtobo expands beyond PAX's initial 67 ha mapping in all directions (Anderson 2011:302) lending a to the possibility of a yet to be discovered production area. This could account for the minimal number of chert tools being recovered despite being a local resource. Until further investigations are carried out at Xtobo the site remains inconclusive.

\section{Evidence for Processed-Blade Trade}

Using the Late Preclassic-Late Classic mixed context sample of 109 prismatic blade segments from Actun Uayazba Kab, the site produces a proximal-distal ratio of 4.1:1, and a medial-distal ratio of 10.4:1. These ratios support the processed-blade trade model. While only seven distal segments were recovered, there were 29 proximal segments and 73 medial segments. The high medial rate could be indication of flintknappers attempting to maximize the number of 
usable blades from a single prismatic blade (De León et al. 2009:115). This is further supported by Stemp et al. not finding cortex on any of the lithics and identifying a predominant number $(n=100)$ of the blade segments as third-series prismatic blades. Third-series blades are produced "with removal from already reduced pressure blade cores" (Stemp et al. 2018:11). Additionally, no primary evidence was recovered. Curiously, two whole prismatic blades, and two pieces of secondary evidence in the form of whole pressure blades, does suggest obsidian may have trickled into the valley in other forms.

Actun Uayazba Kab existed as an auxiliary site to and used by the people of Cahal Uitz Na, and perhaps and pilgrims (Stemp et al. 2018). The late Preclassic-Late Classic mixed sample size is consistent with ratios expected for processed-blade trade, with some evidence of possible whole-blade trade. For Uayazba Kab to receive processed-blades, a location where the obsidian prismatic blades were processed is required. The nearest site that processing could have occurred would be at Cahal Uitz Na. The sparse quantity of distal segments and the whole prismatic blades recovered from Uayazba Kab might be evidence that Uitz $\mathrm{Na}$ was receiving whole-blades which were processed for use in the ritual caves. It's also possible Uitz Na may have been receiving processed-blades too. Further investigation at Utiz Na focusing on Preclassic and Classic obsidian assemblages could enrich Uayazba Kab’s analysis.

\section{Evidence of Mixed Distribution}

The lack of recorded segment sections for Tikal complicated evaluating the site using De Leon's et al.'s method, making only a partial analysis possible. In lieu of data on prismatic blade segments, my analysis focused on primary and secondary production evidence, along with contextual information not necessarily considered by De León et al. During the Middle to Terminal Preclassic, Tikal participated in long-distance distribution networks, granting access to 
all Highland Guatemalan sources, along with Pachuca in central Mexico. Being recipient of multiple obsidian sources could mean different forms of obsidian trade were occurring simultaneously. A larger amount of the Pachuca obsidian from central Mexico recovered has been linked to the influential center of Teotihuacan. There is evidence to suggest Tikal was receiving processed-blades from Teotihuacan.

First, the large number of Teotihuacan thin bifaces found in Tikal raises the "possibility that all thin bifaces of central Mexican type were probably made there" (Moholy-Nagy 1999:304). The production of bifaces, the high quantity of Pachuca prismatic blades, and the low quantity of Mexican obsidian debitage supports Tikal receiving completed obsidian tools and eccentrics. If Teotihuacan was distributing completed lithics, it is possible they were shipping material throughout other production stages depending on distance.

Second is the matter of obsidian structural integrity during long-distance travel. A land route between the Pachuca obsidian source Cerro Las Navajas and Tikal is around 1200km, and between Teotihuacan to Tikal $\sim 1100 \mathrm{~km}$. Even accounting for the possibility of water routes (De León et al. 2009:125), perhaps across or along the coast of the Gulf of Mexico, the route between the two cities was long. In their evaluation of San Jose Mogote in the Valley of Oaxaca, De León et al. concluded that the site was receiving processed-blade trades. The Valley of Oaxaca is roughly $250 \mathrm{~km}$ from the nearest obsidian source, but was receiving "raw obsidian and finished tools" as early as its Middle Preclassic (De León et al. 2009:120). While a whole plethora of cultural, political-economical, and technological factors certainly would impact the state obsidian was distributed in, the sheer distance between Tikal and Teotihuacan, being four times the distance obsidian travelled to get to the Valley of Oaxaca, makes it likely blades were processed to survive such a lengthy land or sea trip. Without blade segments to derive ratios, this is all 
speculative, and the needed evidence to discern between whole-blade trade and processed-blade trade has yet to be recorded.

Obsidian assemblages from Tikal connected to the Guatemalan sources don't align with processed-blade trade, providing further support multiple distribution methods may have been occurring in the city simultaneously. The combined primary and secondary evidence for localblade production occurring at Tikal during the Preclassic include: a blade core from Ixtepeque, and exterior blade flakes and cortical flakes from both El Chayal and San Martín Jilotepeque, along with thousands of unsourced pieces of debitage. By the Early Classic Tikal was recipient of 10 sources of obsidian (Moholy-Nagy 1999:301-302), and a site of mass local production throughout the Classic (Moholy-Nagy 1997). The Preclassic primary and secondary evidence can be interpreted as the local-blade production was established before Tikal's Classis phase.

\section{Conclusion}

This analysis has served as an initial proof-of-concept that De León et al.'s models can be used to interpret obsidian assemblages at Maya sites. The four sites selected for this study each were interpreted to the extent evidence allowed. The segment ratios and production evidence recovered at El Ceibal support local-blade production, which is confirmed by the presence of a Preclassic obsidian workshop. Tikal too shows evidence that Guatemalan obsidian was locally processed, while they were importing processed-blades from central Mexico, likely through Teotihuacan. One of the main limitations I encountered in the analysis were issues in the method obsidians are reported on by researchers. Limited recording of the proximal, medial, and distal segments recovered from sites made calculating necessary ratios impossible, as was the case for Tikal. A second limitation was found in sample sizes. Both Xtobo and Actun Uayazba Kab had small sample sizes for the Preclassic. Xtobo's sparse evidence points towards local-blade 
production, but the lacking production evidence complicates this interpretation, and demonstrates that further investigation is required. Similarly, Uayazba Kab's small Preclassic sample size required being combined with Classic obsidian contexts, which could skew results, though no diachronic change in obsidian besides quantity is seen at the cave between the Preclassic and Classic. Future attempts to validate and expand upon De León et al.'s distribution models may benefit by focusing on Maya Classic phase obsidian assemblages which are better reported, more accessible to investigators, and are in magnitudes higher quantity, and work chronologically backwards. Part of my interpretation of Tikal required looking at how Tikal was operating during the Classic and suggesting an origin to Classic local-production.

Distribution models provide a simple method to make deep interpretations regarding a single-axis of trade, and potential clues into early economic systems. Should prismatic blade segments be identified as routinely as sourcing in the reporting on obsidian artifacts, distribution models could be more frequently inferred, adding another dimension to study. As more sites have distribution models attributed to them, quantitative analyses of distribution trends could be conducted to identify possible locations along the obsidian distribution supply chain. 


\section{Works Referenced}

Adams, R. E. W. (2005). Prehistoric Mesoamerica (3rd ed). Norman: University of Oklahoma Press.

Anderson, D. S. (2005). A Report on Activities at Xtobo, Yucatán, México. Proyecto Costa Maya, 35.

Anderson, D. S. (2010). Xtobo, Yucatan, Mexico; The study of a Preclassic Maya community (Dissertation). Tulane University, New Orleans.

Anderson, D. S. (2011). Xtobo, Yucatan, Mexico, and the Emergent Preclassic of the Northern Maya Lowlands. Ancient Mesoamerica, 22(02), 301-322. https://doi.org/10.1017/S095653611100023X

Andrefsky, W. (2005). Lithics: macroscopic approaches to analysis (2nd ed). Cambridge ; New York: Cambridge University Press.

Aoyama, K. (2017a). Ancient Maya Economy: Lithic Production and Exchange around Ceibal, Guatemala. Ancient Mesoamerica, 28(01), 279-303. https://doi.org/10.1017/S0956536116000183

Aoyama, K. (2017b). Preclassic and Classic Maya Interregional and Long-Distance Exchange: A Diachronic Analysis of Obsidian Artifacts from Ceibal, Guatemala. Latin American Antiquity, 28(02), 213-231. https://doi.org/10.1017/laq.2017.2

Aoyama, K., Inomata, T., Triadan, D., Pinzón, F., Palomo, J. M., MacLellan, J., \& Sharpe, A. (2017). Early Maya Ritual Practices and Craft Production: Late Middle Preclassic Ritual Deposits Containing Obsidian Artifacts at Ceibal, Guatemala. Journal of Field Archaeology, 42(5), 408-422. https://doi.org/10.1080/00934690.2017.1355769

Blomster, J. P., \& Glascock, M. D. (2011). Obsidian procurement in formative Oaxaca, Mexico: 
Diachronic changes in political economy and interregional interaction. Journal of Field Archaeology, 36(1), 21-41. https://doi.org/10.1179/009346910X12707321242278

Braswell, G. E., Clark, J. E., Aoyama, K., McKillop, H. I., \& Glascock, M. D. (2000).

Determining the Geological Provenance of Obsidian Artifacts from the Maya Region: A Test of the Efficacy of Visual Sourcing. Latin American Antiquity, 11(03), 269-282. https://doi.org/10.2307/972178

Brown, K. L. (1980). A Brief Report on Paleoindian-Archaic Occupation in the Quiche Basin, Guatemala. American Antiquity, 45(2), 313-324.

Coe, M. D., \& Flannery, K. V. (1964). The Pre-Columbian Obsidian Industry of El Chayal, Guatemala. American Antiquity, 30(1), 43-49.

Conlon, J. M., \& Ehret, J. J. (1999). Survey at the Major Center of Cahal Uitz Na, Cayo District, Belize. In The Western Belize Regional Project A Report of the 1998 Field Season (pp. 33-44). New Hampshire: University of New Hampshire, Durham.

De León, J. P., Hirth, K. G., \& Carballo, D. M. (2009). Exploring Formative Period Obsidian Blade Trade: Three Distribution Models. Ancient Mesoamerica, 20(01), 113. https://doi.org/10.1017/S0956536109000091

Ebert, C. E., Dennison, M., Hirth, K. G., McClure, S. B., \& Kennett, D. J. (2015). Formative Period Obsidian Exchange along the Pacific Coast of Mesoamerica: Formative Period obsidian exchange in Mesoamerica. Archaeometry, 57, 54-73. https://doi.org/10.1111/arcm.12095

Ferguson, J. M., \& Gibbs, S. (1999). Report on The 1998 Excavations at Actun Uayazba Kab, Roaring Creek Valley, Belize. In The Western Belize Regional Project A Report of the 1998 Field Season (pp. 112-145). New Hampshire: University of New Hampshire, 
Durham.

Ferguson, J. R. (2012). X-Ray fluorescence of obsidian: Approaches to calibration and the analysis of small samples. In A. N. Shugar \& J. L. Mass, Handheld XRF for art and archaeology (pp. 401-422). Leuven, Belgium: Leuven University Press. Retrieved from http://public.eblib.com/choice/publicfullrecord.aspx?p=1763017

Glascock, M. D. (2017a, June 2). Overview of Neutron Activation Analysis [University of Missouri]. Retrieved February 18, 2018, from http://archaeometry.missouri.edu/naa_overview.html

Glascock, M. D. (2017b, June 17). Frequently Asked Questions [University of Missouri Research Reactor]. Retrieved February 18, 2018, from http://archaeometry.missouri.edu/faq.html

Griffith, C. S. (1998). Excavations and Salvage Operations in ActunTunichil Muknal and Actun Uayazba Kab, Roaring Creek Valley, Belize. In The Western Belize Regional Project A Report of the 1997 Field Season (pp. 37-70). New Hampshire: University of New Hampshire, Durham.

Griffith, C. S. (1999a). An Alternative Interpretation of Monument 1 in the Stela Chamber of Actun Tunichil Muknal. In The Western Belize Regional Project A Report of the 1998 Field Season (pp. 105-111). New Hampshire: University of New Hampshire, Durham.

Griffith, C. S. (1999b). Patterns in the Darkness: Report on the 1998 Investigations in Actun Uayazba Kab, Belize. In The Western Belize Regional Project A Report of the 1998 Field Season (pp. 85-104). New Hampshire: University of New Hampshire, Durham.

Guthrie, J. M., \& Ferguson, J. R. (2012, August). Overview of X-ray Fluorescence. Retrieved January 14, 2018, from http://archaeometry.missouri.edu/xrf_overview.html 
Hirth, K. G. (1998). The Distributional Approach: A New Way to Identify Marketplace Exchange in the Archaeological Record. Current Anthropology, 39(4), 451-476. https://doi.org/10.1086/204759

Hodgman, D. R. (2001). Actun Nak Beh and Cahal Uitz Na: Analysis and Interpretation for Sacred Geography and Regional Latice (Thesis). University of Pennsylvania, Philadelphia, Philadelphia.

Hughes, R., \& Fortier, A. (2007). Trace Element Analysis of Obsidian Artifacts from Six Archaeological Sites in Illinois. Illinois Archaeology, 19, 144-157.

Lohse, J. C. (2010). Archaic Origins of the Lowland Maya. Latin American Antiquity, 21(3), $312-352$.

Moholy-Nagy, H. (1994). Tikal material culture: Artifacts and social structure at a classic lowland Maya city (Dissertation). The University of Michigan, Michigan.

Moholy-Nagy, H. (1999). Mexican Obsidian at Tikal, Guatemala. Latin American Antiquity, $10(3), 300-313$.

Moholy-Nagy, H. (1997). Middens, Construction Fill, and Offerings: Evidence for the Organization of Classic Period Craft Production at Tikal, Guatemala. Journal of Field Archaeology. 24(03), 293-313.

Moholy-Nagy, H., \& Nelson, F. W. (1990). New Data on Sources of Obsidian Artifacts from Tikal, Guatemala. Ancient Mesoamerica, 1(01), 71-80. https://doi.org/10.1017/S0956536100000080

Nadin, E. (2007). The Secret Lives of Minerals. Engineering \& Science, 70(1), 10-20.

Paris, E. (2012). Cohesion and Diversity in Formative Period Maya Lithic Tools and Techniques. Lithic Technology, 37(2), 111-140. https://doi.org/10.1179/lit.2012.37.2.111 
Pierce, D. E. (2015). Visual and geochemical analyses of obsidian source use at San Felipe Aztatán, Mexico. Journal of Anthropological Archaeology, 40, 266-279. https://doi.org/10.1016/j.jaa.2015.09.002

Shackley, M. S. (Ed.). (2011). An Introduction to X-Ray Fluorescence (XRF) Analysis in Archaeology. In X-Ray Fluorescence Spectrometry (XRF) in Geoarchaeology (Kindle). New York: Springer.

Stemp, W. J., Peuramaki-Brown, M., \& Awe, J. J. (2018). Ritual economy and ancient Maya bloodletting: Obsidian blades from Actun Uayazba Kab (Handprint Cave), Belize. Journal of Anthropological Archaeology. https://doi.org/10.1016/j.jaa.2018.07.003

Tischler, A., \& Anderson, D. S. (2018). Obsidian lithics discovered by PAX at Xtobo.

Wirth, K., \& Barth, A. (2017, May 16). X-Ray Fluorescence (XRF) [University]. Retrieved January 14, 2018, from https://serc.carleton.edu/research_education/geochemsheets/techniques/XRF.html Wrobel, G. D., Freiwald, C., Michael, A., Helmke, C., Awe, J., Kennett, D. J., Griffith, C. (2017). Social identity and geographic origin of Maya burials at Actun Uayazba Kab, Roaring Creek Valley, Belize. Journal of Anthropological Archaeology, 45, 98-114. https://doi.org/10.1016/j.jaa.2016.11.004 